\title{
民意形成の政治過程 $\mathrm{JR}$ 東日本(侏信濃川発電所の水利権取り消し問題を事例に
}

\section{田洋 直樹*}

\section{I はじめに}

水力発電所のデー夕改竄事件と、同水利権取り 消し事件の最悪の事例となった JR 東日本(株)信濃 川発電所の違法取水に対する十日町市の水なしサ ミット運動は、大きな成果を上げた。(1) 40 $120 \mathrm{~m}^{3} / \mathrm{s}$ もの河川維持用水は、1989年大井川の水 返せ運動で獲得された $3 \sim 5 \mathrm{~m}^{3} / \mathrm{s}$ 以来、最高水準 のものとなったこと。(2)河川利用率から利水量 · 維持流量を算出した最初の事例となったこと。(3) 自然流況 (時間) 変動型維持流量の試行を採用し たこと1)、である。本稿ではこれらを踏まえ、JR 東日本(株)水利権再取得時に十日町市が同意したと き、本問題に対しての市民の本音に触れながら、 どの段階まで市民参加が為されたのかを考察した いと思う。

\section{JR 東日本(株)信濃川発電所の水利権同意 問題と歴代市長のスタンス}

JR 東日本(株が如何に日本を代表する巨大企業で あったとしても、地元基礎自治体が同意しなけれ ば信濃川水力発電所は増設されなかった。以下歴 代十日町市長の水利権問題に対するスタンスを略 述する中で、その過程を概観したい。

\section{1 余剰水利権に同意した諸里市長}

事の発端は、1984年 8 月 31 日諸里正典市長が、 $J R$ 東日本(株)の余剩水利権取得に対して同意した ことである。1980年代初め信濃川を蘇らせる会(以 下、信蘇会) だけでなく市長自身も反対していた にも拘わらず、84年になると諸里は市議会へ諮 ることもせず、行政 (市長)の専決事項として同

* ATT 流域研究会
意した2)。また彼は余剩水利権と引き替えに、日 本国有鉄道から支援を受け流雪溝用水 ${ }^{3)}$ や笹山競 技場 ${ }^{4)}$ を建設したため、評価する市民もいる。

\section{己 水なしサミットを始めた本田市長}

諸里市長の助役を務めた本田欣二郎は、丸山尚 政市長の後、1993年12月15日市長に就任する。 そして諸里市長と激しく対立した信蘇会とこれに 続く信濃川をよみがえらせる会 (以下信よ会) ${ }^{5}$ に 関わってきた樋熊清治に協力し、97年に改正され た河川法もあって市役所が水なしサミット運動を 展開する6)。彼は「我々の水を返せ」と要求し、 1998年には4万 $5 千 も の$ 署名活動と決起大会を行 い、住民を連れて JR 東日本(株)の本社に乗り込ん だ。これらの努力が、1999年信濃川中流域水環 境改善検討協議会 (表 1 ) の設立に結びつき、同 年 9 月に始めた水なしサミットは、2010年まで毎 年開催されてきている。

\section{3 合併による影響}

2005年 4 月十日町市は、中魚沼郡中里村と同郡 川西町、東頸城郡松代町、同郡松之山町を併せ、 前川西町長の田口直人が市長に当選した。その結 果合併前、JR 東日本(侏)信濃川発電所宮中ダムが 中里村に、浅河原調整池が十日町市に、千手発電 所が川西町に位置したのに対し、合併後は3施設 全てが十日町市に位置することになった。この合 併が本件の受益・受苦関係を変容させる。すなわ ち合併前、信濃川発電所から生じる固定資産税等 による受益は各市町村に分配されるのに反し、涸 れ川公害等の受苦は主に旧十日町市に抱えさせら れていた。しかし合併後は、受益と受苦の双方を 新生十日町市が抱えることになると同時に、水利 
権取得および更新に対する地元側空口が十日町市 に一本化された。

\section{4 穞健派市長の行政的解決へ}

2005 年 5 月市長に就任した田口直人も、信濃川 の環境改善に取り組んだ。

\section{（i）違法取水の実態}

2006 年 10 月 31 日岡山県の土用ダムで、同年 11 月28日群馬県の野反ダムでデー夕改竄が発覚し、 国土交通省 (以下、国交省)が全国一斉調査を行っ た。国交省の自主点検要請に対し、JR東日本(株) は 2007 年 3 月7) と 2008 年 3 月「取水は適正」との虚 偽回答を故意に行った。2008年6月の十日町市議 会 6 月定例会で、市議兼信よ会副会長の根津東六 が取水量実績值の情報公開を提案し、同年 7 月十 日町市役所が国土交通省北陸地方整備局信濃川河 川事務所 (以下、信濃川河川事務所) に取水実績 についての情報公開請求を行った ${ }^{8)}$ 。信濃川河川 事務所は 08 年 8 月取水デー夕に異常值があること に気付き、08年 9 月 20 日国交省が立ち入りで上 限リミッター9)の稼働が、12月6日には下限リミッ ター10)の稼動が判明した。更にこの後超過取水量 や流量不足などが判明し、11月8日には信濃川水 環境改善検討協議会 (以下、検討協議会) で定め られた宮中ダムからの試験放流量を故意に 4 割 カットしていた悪事も11 発覚した。これらの結果 $\mathrm{JR}$ 東日本(秼)の犯した違法取水は、約 7 年間で約 3 億 1 千万 $\mathrm{m}^{3}$ 以上に達する ${ }^{12)}$ 。

\section{（ii）水利権取り消しとなった要因}

水力発電所の水利権が取り消されたのは、本件 が2件目である。取り消しとなった理由として、 北陸地方整備局 (以下、北陸地整) の広域水管理 官は ${ }^{13)} 『$ 水が消えた大河で』 14)に倣って、(1)膨大な 違法取水量、(2)虚偽回答、(3)検討協議会を欺いた こと、の3点を挙げる。(1)は、2007年に発覚した 東電株塩原発電所の違法取水量の 4 倍弱にも当た る。(2)の虚偽回答は故意に2回も行うほど悪質で ある。(3) 10 年間も開催された検討協議会で決 められた試験放流量を故意に 4 割もカットするこ とで、地元だけでなく国や県、学識経験者までも 欺いた。広域水管理官は、(1)だけなら水利権取り 消しとはならなかった、(2)と(3)が、特に(3)が悪質
であるとの認識を示した。更に2008年5月19日 国交省が「不適切事案の再発防止に向けての指 導・監督の在り方について」を通知し、その「(3) 河川管理者の取り組むべき事項の(3)には、「特 に重大な違反や虚偽報告等悪質な違反に対しては、 厳格に対処する」と記されている。これが、北陸 地整の水利権取消処分を後押しする要因となった、 と言えるだろう。

違法取水発覚後の 2008 年 11 月 13 日 JR 東日本(侏) は十日町市で住民説明会を、11月15日には国交省 が住民懇談会を開催し、違法行為の周知を図った。 2009 年 1 月に入り、信よ会は 1 月 27 日信濃川発電 所を訪ね取水の即刻停止を「要求」15)したが、1月 30 日田口市長は JR 東日本(株)の本社訪ね、(1)年度 末に予定している検討協議会の提言を尊重するこ と、(2)地域と共生し貢献する企業に変わること等 を「要請」16) した。国交省が JR 東日本(侏)信濃川発 電所の水利権取消処分に着手した 09 年 2 月 13 日、 田口市長は早くも JR 東日本(株)の水利権再申請を 容認すると同時に、水力発電はクリーン・エネル ギーとの認識を示している17)。2月16日田口市長 と市議会は清野智社長の謝罪を受け入れた ${ }^{18)}$ 。

国交省の水利権取り消しを受けて、県知事は2 月 16 日に 2 市 1 町 (小千谷市、十日町市、川口町) に意見照会をした上で 2 月 25 日に、経済産業相は 3 月 6 日に「異議なし」と国交省に回答した ${ }^{19}$ 。3月 8 日十日町市役所ほか 10 団体は「JR 東日本信濃川 発電所の違法取水に抗議する緊急集会」を開催し、 1,100 人の市民が出席した ${ }^{20)}$ 。 3 月 10 日国交省は $J R$ 東日本(侏信濃川発電所の水利権を取り消した ${ }^{21)}$ 。 田口市長は JR 東日本(株に違法取水によって被害 を受けた市民に謝罪することを、強く求めた。3 月 11 日 JR 東日本(株は社内処分を発表したが、引 責辞任は 1 人もなく軽い処分となった ${ }^{22)}$ 。 4 月同 社は小千谷市の同発電所内に「信濃川発電所業務 改善事務所」を設置し ${ }^{23} 、 4$ 月 16 日十日町市役所ほ か 10 団体は JR 東日本発電取水総合対策十日町市民 協議会 (以下、市民協議会) を設立した (表 1 ) ${ }^{24)}$ 。 この時期国交省は JR 東日本(株に対し、地元農業 用水向けの水利権を限定的に許可したため、従属 発電が発生した。近藤正道参議院議員 (当時、新 潟選挙区）は4月 27 日同決算委員会で、「JR 東日 
表 1 十日町市役所が関わった水なしサミット運動に関わる諮問機関等一覧

\begin{tabular}{|c|c|c|c|c|}
\hline 年月 & 称 & 事務局 & 公開性 & 委 員 構 成 \\
\hline 99. & $\begin{array}{l}\text { 信濃川中流域水環境 } \\
\text { 改善検討協議会 }\end{array}$ & $\begin{array}{c}\text { 信濃川 } \\
\text { 河川事務所 }\end{array}$ & 公開 & $\begin{array}{l}\text { 北陸地方整備局：水政課、河川管理課、信濃川河川事務所、千曲川河 } \\
\text { 川事務所 } \\
\text { 基本自治体：新潟県河川管理課、長野県河川課・水環境課 } \\
\text { 基礎自治体：新潟県十日町市、長野県飯山市、新潟県津南町、長野県 } \\
\text { 栄村 } \\
\text { 学識経験者：経済学者 (会長)、魚類学者、生態学者、河川工学者 } \\
\text { オブザーバー：JR 東日本(株、東京電力(株) }\end{array}$ \\
\hline 09.4 & $\begin{array}{l}\text { JR 東日本発電 } \\
\text { 取水総合対策 } \\
\text { 十日町市民協議会 } \\
\text { (市民協議会) }\end{array}$ & $\begin{array}{l}\text { 市役所克雪 } \\
\text { 維持課 }\end{array}$ & 非公開 & $\begin{array}{l}\text { 市長 (会長)、市議会議長、商工会議所、JA 十日町、十日町土地改良区、町 JC、中魚沼漁協、信よ会 } \\
\text { 川西土地改良区、中里土地改良区、十日町 }\end{array}$ \\
\hline 09.9 & $\begin{array}{l}\text { 信濃川発電所 } \\
\text { 宮中取水名魚道 } \\
\text { 構造改善検討委員会 } \\
\text { (魚道委員会) }\end{array}$ & $\begin{array}{c}\mathrm{JR} \text { 東日本 } \\
\text { (株) }\end{array}$ & 非公開 & $\begin{array}{l}\text { 有識者: 新大名誉教授、埼大教授、長岡技科大教授、信濃川河川事務所 } \\
\text { 中魚沼漁協、十血町副市長、県内水面水産試験場、JR東日本(株信濃 } \\
\text { 川発電所業務改善推進部長 }\end{array}$ \\
\hline 10.1 & $\begin{array}{l}\text { 信濃川の在り方 } \\
\text { 委員会 } \\
\text { (在り方委員会) }\end{array}$ & $\begin{array}{c}\text { 市役所 } \\
\text { 克雪維持課 }\end{array}$ & 公開 & $\begin{array}{l}\text { 委員 : 市長、市議会議長、商工会議所、JA十日町、十日町土地改良区 } \\
\text { 川西土地改良区、中里土地改良区、町 JC、中魚沼漁協、信よ会 } \\
\text { 助言者：河川工学者、コンサ川研究員、ラフティング業者 } \\
\text { オブザーバー: JR 東日本(株)十日町改善事務所長 }\end{array}$ \\
\hline 10.1 & $\begin{array}{l}\text { JR 水利申請専門部会 } \\
\text { (専門部会) }\end{array}$ & $\begin{array}{c}\text { 市役所 } \\
\text { 克雪維持課 }\end{array}$ & 非公開 & $\begin{array}{l}\text { 権利者：十日町市、十日町土地改良区、中魚沼漁協 } \\
\text { 助言者：信よ会、河川工学者、コンサ研究員 } \\
\text { オブザーバー：JR 東日本(株十日町改善事務所長 }\end{array}$ \\
\hline
\end{tabular}

本(株棚ぼた発電収益を地元に還元すべき」25) と質 問している。4月26日の十日町市長選で田口直人 市長は落選し、5月 1 日関口芳史 (前三条市収入役、 旧十日町市出身)が市長に就任した。

\section{5 原則派市長の行政的解決へ}

5 月 21 日 JR 東日本(侏)の清野智社長は関口市長 を訪ねて謝罪したが、合法的取水が信濃川の河川 環境を破壊したとの認識はなく、同市長は同社が 再申請するための維持流量の議論を門前払いにし た ${ }^{26)}$ 。6月に同社の役員が十日町市を謝罪に訪問 し、6月18日社長名で 2 市 1 町の約 35,000戸に謝 罪文を郵送した ${ }^{27)}$ 。7 月関口市長は自民党と JR の不正取水についての勉強会を 2 回行い、JR 東 日本(侏)など自家用発電所を(1)電源三法の対象とす ること、流水占用料を都道府県ではなく(2)市町村 に納付することの 2 点について、法改正に向けた 要望を河川局長に出している28)

9 月 8 日 JR 東日本(株)は、JR 信濃川発電所宮中 ダム魚道構造改善検討委員会 (以下、魚道委員会) を設置した (表 1 ) 29)。10月の1ケ月間、宮中ダム を遡上した鮭は 164 匹と例年の 5 倍にも上り、信 濃川中流域の蘇生が実証された。一方 10 月 30 日 〜 11 月 1 日 JR 東日本(株)は、千手発電所を初めて 一般公開する ${ }^{30)}$ と共に、合法的な取水が信濃川の
環境を著しく破壊してきたことを認め始めた。こ れを受けて関口市長は11月16日の第3回市民協 議会で、適法な取水であっても河川環境を破壊し てきたとの認識を共有することを要求し、JR東 日本(侏)との再申請交渉の開始を表明した ${ }^{31)} 。 11$ 月 25 日清野 JR 東日本(株社長は、市議会議場で十日 町市民に謝罪し、30億円を詫び金として拠出す ることを表明した ${ }^{32}$ 。

2010年に入ると関口市長は、水利権再申請同 意に向けて全市民の賛同を取り付けるべく、1月 13 日市民協議会の下に信濃川の在り方検討委員 会 (以下、在り方委員会)を、1月20日その下に $\mathrm{JR}$ 水利申請専門部会 (以下、専門部会) を設置し

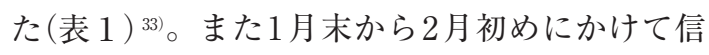
濃川あるべき姿市民懇談会 (以下、市民懇談会)

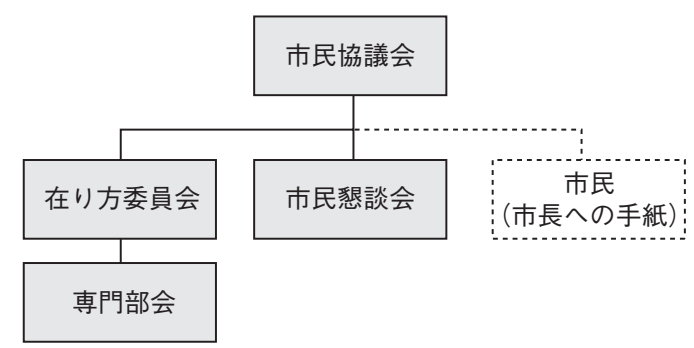

図 1 水利権再取得時における十日町市の 諮問機関の構成 


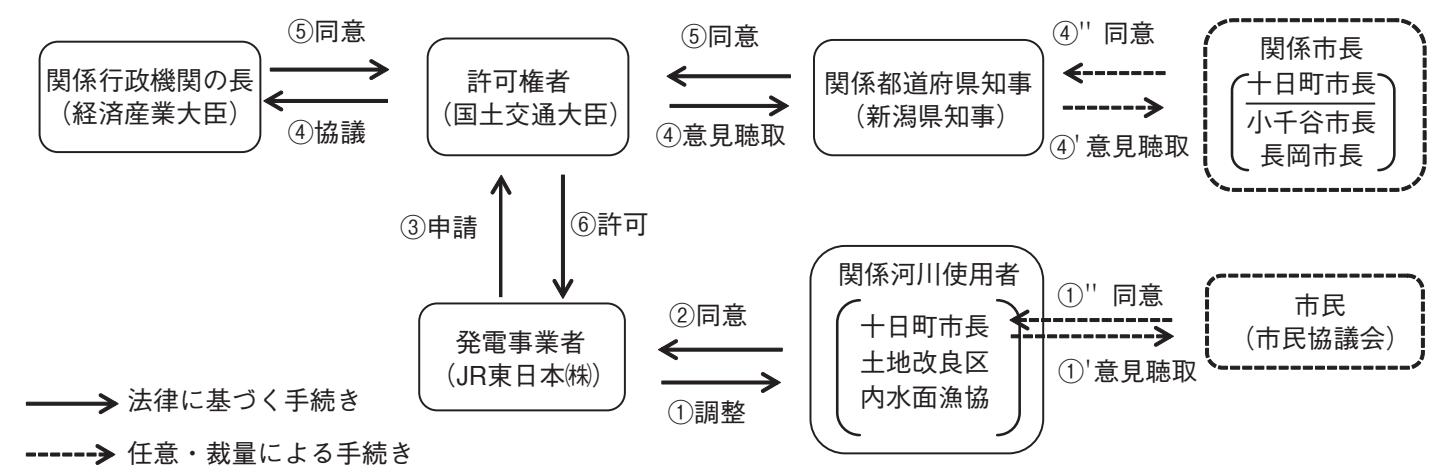

図2 信濃川における JR 東日本発電用水の水利権更新時の手続きフロー

(本件の場合、一旦水利権取消処分を受けたため、新規申請と同等の手続きである)

を開き、さらに「市長への手紙」を募集して、市 民から意見を聴取した (図 1$)^{34)}$ 。そして 2 月 26 日 の第 3 回在り方委員会で、最大取水量 $317 \mathrm{~m}^{3} / \mathrm{s}$ 、 $40 \sim 120 \mathrm{~m}^{3} / \mathrm{s}$ の変動型維持流量を 5 年間試験放流 することで、JR 東日本(株とほぼ決着した ${ }^{35)}$ 。

しかし関口市長は市民への説明と同意を優先す ベく、3月1日の市民協議会での同意を先送りし たので ${ }^{36)}$ J JR 東日本(株)は水利権の申請期限を 1 ケ 月延長した ${ }^{37}$ 。3 月 18 日市長は、市民協議会と共 に「信濃川の河川流量の決定に向けた市民説明 会」を開催して市民の同意を得た ${ }^{38)}$ 。3 月29日市 議会は市長が再申請に同意することを議決し ${ }^{399}$ 、 3 月 30 日水利使用についての「協定書」と「十日町 市と JR 東日本発電所の共生に関する覚書」、「試 験放流に関する確認書」に調印し十日町市と土地 改良区、内水面漁協の関係河川使用者は JR 東日 本(侏)の再申請に同意した ${ }^{40)}$ 。 4 月 2 日 JR 東日本(株 は信濃川発電所の水利権を再申請し41)、6月9日国 交省は JR 東日本(侏)の水利権を許可した(図 2$)^{42)}$ 。

\section{III 水利権取り消しを巡る運動の意義と課題}

\section{1 意義}

今回の水なしサミット運動は約 1 年半の短い間 に決着がついたが、「Iはじめに」で挙げた 3 点以 外にも涸れ川公害回復運動として大きな成果が あったと考える。以下に指摘したい。

第 1 に、清野智 JR 東日本(株)社長は違法取水が 発覚した当初、09年 2 月 16 日田口十日町市長と市 議会全員協議会に対する挨拶では、違法取水につ いてのみ謝罪した。また09年6月18日に社長名で
2市1町の35,000戸に出した書簡においても、謝罪 したのは違法取水のみである。さらに09年3月の 検討協議会にオブザーバー出席した JR 東日本(株) 信濃川発電所長も、「当発電事業で河川環境を破 壊していると思わない」と取材に答えている ${ }^{43)}$ 。 つまり1984年に取得した水利権による合法的な 取水なら、信濃川が涸れて魚がいなくなり、井戸 が涸れて地元住民が水を飲めなくなっても、JR 東日本(侏)には何の責任もないというのである。

しかし関口市長による水利権交渉の門前払いが 切欠となって、JR 東日本(侏)は合法的な取水であっ ても信濃川の環境を破壊してきたことを認め、そ の改善策に着手せざるを得なくなった。つまり法 的に認められた水利権であっても、河川環境の受 忍限度を超えた破壊であると公的に認められれば、 発電事業者は地元のため、水利権の一部を返上し なければならなくなったのである。今後合法的な 取水でも河川環境を破壊していないかという認識 は、全国に波及するに違いない。

第 2 に、発電水利権による涸れ川公害に対して は、現行では水利権更新・再取得時に措置が執ら れる。発電事業者は、国交相への申請前に関係河 川使用者 (本件では十日町市長、土地改良区、内 水面漁協、3月 30 日)の同意を得てから、河川 (国 道) 事務所に申請し(4月 2 日)、その後当該地方整 備局へ、更に国交相 (河川管理者)に上程される。 またこのとき審査で参照される法規は、「10項目」 と「発電ガイドライン」である。同相は農水相な ど関係大臣と協議し(河川法35条、6月1日)、ま た当該都道府県知事から意見聴取 (河川法 36 条) 


\begin{tabular}{ccccc} 
表2 & \multicolumn{4}{l}{ 維持用水の増量 } \\
\hline 年 & 河川名 & ダム・堰堤名 & 維持流量 $\left(\mathrm{m}^{3} / \mathrm{s}\right)$ & 比流量 $\left(\mathrm{m}^{3} / \mathrm{s} / 100 \mathrm{~km}^{2}\right)$ \\
\hline 1989 & 大井川 & 塩郷堰堤 & $3 \sim 5$ & $0.31 \sim 0.52$ \\
2000 & 筑後川 & 大山川揠堤 & $1.8 \sim 4.5$ & $0.35 \sim 0.877$ \\
2001 & 四万十川 & 家地川堰堤 & $1 \sim 3.40$ & $0.26 \sim 0.90$ \\
2005 & 大井川 & 田代ダム & $0.43 \sim 1.49$ & $0.40 \sim 1.37$ \\
2010 & 信濃川 & 宮中ダム & $40 \sim 120$ & $0.51 \sim 1.53$ \\
\hline
\end{tabular}

を行った。知事は3市長 (十日町市、小千谷市、 長岡市、6月 2 日) に意見聴取を行っている(図 2 (4)' (4)"の点線部分) が、この行為は河川法上に規 定されておらず、知事の裁量において執行された ${ }^{44)}$ また十日町市長がこのとき回答した同意は、行政 の長としてのものである。経産相 (6月 7 日) と知 事 (6月8日) が異議なしと回答したため、国交相 は JR 東日本(株に水利権を許可した (6月9日)。本 件に於いては、水利権が取り消されてから発電事 業者が関係河川使用者から同意を得るまで約 1 年 以上も要したのに対して、発電事業者が申請をし てから河川管理者が水利権を許可するまでは約 2 か月間しか掛かっていない。このように申請前の 地元同意に、多大なエネルギー（両者間の闘争） と期間が必要とされ、申請後の手続きよりも遙か に重大なことがわかる。逆に言えば、この申請前 同意を捉え損なえば、地元の要望は通らないので ある。今回は発電事業者の違法取水・水利権取り 消しという敵失によって、絶対的に有利な状況に あったことも忘れてはならない。

\section{2 今後の課題}

大きな成果を上げた今回の運動も、以下のよう な課題が挙げられる。

第 1 に現在の法制度では発電水利権の取得 ·更 新の過程に、加害者としての発電事業者と県知事 しか関与できず、被害者である一般の住民・市民 や市民団体はもとより、市町村長や市議、そして 県議までも排除されている。この点を本省水政課 水利審査係長に尋ねると、「河川法上の知事は個 人としての知事ではなく、機関としての知事であ る。従って土木部や土木事務所の担当者が県民か ら意見を聴取しているので、知事が県民の総意を 代弁していることには間違いない」との回答で あった。けれども、元長野県知事の田中康夫は県
内各地で「出前トーク」を開催していたが、新潟 県知事が同様な活動を行ったとは聞いていない。 偶々十日町市は流雪溝用水と灌溉用水を所有して いたので、関口市長は関係河川使用者としての申 請前の同意過程に、市民懇談会等を設置して市民

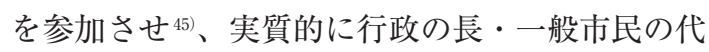
表として同意という工夫をしたのである(図 2 1) (1)"の点線部分)。被害者としての住民・市民が関 与できるように、河川法上も改正する必要がある のではないか。

第 2 に、今回の水なしサミット運動により、十 日町市民は $40 \sim 120 \mathrm{~m}^{3} / \mathrm{s}$ という最高水準の河川 維持用水を獲得した ${ }^{46)}$ 。表 2 を見れば、1988〜 89年大井川中流域における「水返せ運動」以来、 維持流量が着実に増えてきたことがわかる。しか しその比流量 $0.51 \sim 1.53 \mathrm{~m}^{3} / \mathrm{s} / 100 \mathrm{~km}^{2}$ という数值 は、発電ガイドラインに規定されている $0.1 〜$ $0.3 \mathrm{~m}^{3} / \mathrm{s} / 100 \mathrm{~km}^{2}$ という数值を著しく逸脱している ${ }^{47)}$ そこで発電ガイドライン改定について尋ねると、 国土交通省河川局河川環境課流水管理室水利係長 ${ }^{48}$ は「発電ガイドラインには、概ね $0.1 〜 0.3 \mathrm{~m}^{3} / \mathrm{s} /$ $100 \mathrm{~km}^{2}$ とあり、更にこれを超えても、また下っ ても良いと書いてあるので、改定する必要はない」 との回答であった ${ }^{49)}$ 。しかし宮中ダム地点におけ る比流量の下限 $0.51 \mathrm{~m}^{3} / \mathrm{s} / 100 \mathrm{~km}^{2}$ で発電ガイド ラインの上限 $0.3 \mathrm{~m}^{3} / \mathrm{s} / 100 \mathrm{~km}^{2}$ 超えており、上 限の比流量 $1.53 \mathrm{~m}^{3} / \mathrm{s} / 100 \mathrm{~km}^{2}$ に至っては $0.3 \mathrm{~m}^{3} /$ $\mathrm{s} / 100 \mathrm{~km}^{2}$ の 5 倍を超えている。つまり現実は発電 ガイドラインを破綻させている。

更に、1896年治水を法目的とした河川法が大日 本帝国政府によって制定され、1958年10項目 ${ }^{50)}$ 日本国政府によって策定され、1964年に法目的 に利水を追加した河川法改正が行われた。そして 1988年通達「発電ガイドライン」が策定されて発 電水利権更新時に効力を発揮し、1997年法目的 
に環境保全を追加した河川法改正が行われた。21 世紀は環境の世紀といわれ、オイル・メジャーな ら好メジャーが世界を席巻すると危惧されてい る。このように、発電ガイドラインだけでなく 10項目の策定時の河川法の理念や時代的要望、世 論の変化などからを考慮すれば、その改正が不可 避であると考える。

第3に、水利権取り消しを巡る水なしサミット 運動は活発に行われたが、市民全体の意見はどう であったのか。運動の中心であった信よ会の前進 である信蘇会は1982年に結成されているので、 その業績は多大である。但し2009年1月末に執行 部が交代した後、副会長が脱会して「千曲川・信 濃川復権の会」を設立し、宮中ダムの撤去を主張 しているし 51 、元会長が参加する「信濃川を愛す

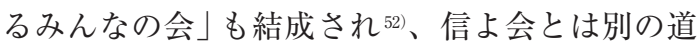
を歩んでいる。また信よ会も加入し、交渉の主役 を演じた市民協議会は、市内 10 団体の代表から 構成される、所謂「政・官・業鉄の三角形」の地 方版である。これは発電所やダムなど公共事業を 進める際に、地元住民が賛成していると事業の推 進にお墨付きを与え、見返りに何らかの利益を獲 得する団体ではないだろうか。市民協議会の構成 員である十日町商工会議所の会頭は、2009年3月 24 日の通常総代会で、「漁協・信よ会の長年の水 に対する拘り、環境保全の思いもあろうが、水を 取り賠償金を勝ち取って欲しい」と述べている。 同時に副会頭は、「JR 関連の事業所を持ち込めな いか」と発言し、2010年3月 30 日締結の「共生に 関する覚書」を彷彿させる ${ }^{53)}$ 。同月農事会社「千手」 の社員は、「JR 以外誰が水を確保できる。・... 違反しようがしまいが、俺たちは水が貴えるかど うかだけだ。と述べ、発電による信濃川の環境 破壊どころか、違法取水という犯罪まで容認して いる ${ }^{54}$ 。十日町市民と雖も、信濃川の環境回復を 望む人ばかりではない。また 2010 年当初開かれ た「市民懇談会」には延べ330人が参加し、「市民 の手紙」には 94 通の応募があった。その結果は、 約 8 割の人が JR 東日本(株)との共生 (取水容認)を、 約 2 割の人が取水拒否、というものであった。更 にこの水なしサミット運動を牽引した信よ会の会 長は、内水面漁協組合長が兼ねている。組合長は
関係河川使用者であるため、市民協議会、在り方 委員会、専門分会、魚道検討会の委員を委嘱され、 大変重要な立場にある。市民協議会など、市よ会 と漁協の代表として参加する場合、2 票の投票権 を持っている。組合長は、当初 JR 東日本(株に対 して強硬な姿勢を取っていたが、結局 $317 \mathrm{~m}^{3} / \mathrm{s}$ の 取水を容認した。更に2010年3月1日の市民協議 会で市長が同会議の公開を提案したとき、組合長 は公開に反対し、JR 東日本(株)への早期同意を主 張している。田口直人前市長は「水はあらゆる生 物が生きるために不可欠なもので、何も語れない 魚や水辺に棲む動植物、これらの生態系の叫びを 代弁できるのは地域に住む私たちであり、大きな 責任がある。」55) と述べている。また「本来は地域 振興より河川環境を議論すべきなのに」56) と当時 の風潮を憂える人もいる。自然保護団体のスタン スだけで活動できる人を、市民団体の代表に選ぶ ベきではないか。

\section{IV おわりに}

今回の調査では、地元の有志にお世話になった。 そして十日町市役所信濃川・清津川対策室や新潟 県庁土木部水政課、国交省河川局水政課・河川環 境課、同省北陸地方整備局水政課、信濃川中流域 水環境検討協議会や在り方委員会の委員にも、 様々なご教示を受けた。これらの方々の他、ここ に記さない方々にも、この場を借りて厚くお礼申 し上げる。また今回の運動で、実務に携わった市 役所担当部局や信よ会その他の市民団体の方々は、 県や国、JR 東日本(侏など上位機関・企業との交 渉に圧迫感を受けながらも奮闘された。敬意を表 するものである。

\section{注}

1）「大熊孝『信濃川のあり方検討委員会』提案の特徵 と意義」(JR 東日本発電取水総合対策十日町市民 協議会『信濃川の河川流量の決定に向けた市民説 明会』2010年 3 月 18 日)

2）三浦英之『水が消えた大河で JR 東日本・信濃川 大量不正取水事件』現代書館、2010年8月 15 日、 $36 \sim 38$ 頁

3）同上、99頁

4）『週報とおかまち』2009年11月 27 日 
5）信濃川を蘇らせる会 (1982年設立、山内正豊会 長) と信濃川の水資源を守る市民会議 (1987年設 立、酒井学会長) が合同し、1996年信濃川をよ みがえらせる会 (樋熊清治会長) が発足した。樋 熊は 82 年当初からの会員である。

6）十日町市役所克雪・利雪対策室の担当者がこの 件に対し河川法改正の重要性に言及した。

7）前揭『水が消えた大河で』、138頁

8）『十日町タイムス』2008年11月18日

9）上限リミッターとは、河川法で許可された最高 取水量 $317 \mathrm{~m}^{3} / \mathrm{s}$ を超えて取水しても、 $317 \mathrm{~m}^{3} / \mathrm{s}$ と記録されるプログラムである。

10）下限リミッターとは、 $7 \mathrm{~m}^{3} / \mathrm{s}$ と決められた河川 維持用水が $7 \mathrm{~m}^{3} / \mathrm{s}$ を下回っても、 $7 \mathrm{~m}^{3} / \mathrm{s}$ と記録 されるプログラムである。

11）『新潟日報』2008年 12 月 2 日

12)「信濃川の今 減水問題と JR 東日本の違法行 為」十日町市、2009年 2 月 2 日

13）2010年 8 月 16 日北陸地方整備局を訪ね、同官か ら聴取した。

14）前揭『水が消えた大河で』184〜 185頁

15）『週報とおかまち』2009年 1 月 30 日

16）『新潟日報』2009年 1 月 31 日

17）『十日町新聞』2009年 2 月 17 日

18）『新潟日報』2009年 2 月 15 日

19)『読売新聞』2009年 3 月 6 日

20）『十日町新聞』2009年 3 月 10 日

21）『新潟日報』2009年 3 月 11 日

22)『十日町新聞』2009年 3 月 15 日

23)『日本経済新聞』2009年 6 月 6 日

24)『読売新聞』2009年 4 月 17 日

25）『十日町新聞』2009年5月 9 日

26）『週報とおかまち』2009年 5 月 29 日

27 『毎日新聞』2009年 6 月 19 日

28）『十日町新聞』2009年 7 月 20 日

29）『週報とおかまち』2009年 9 月 11 日

30)『朝日新聞』2009年11月 1 日
31)『津南新聞』2009年 11 月 20 日

32 )『読売新聞』2009年 11 月 26 日

33 )『津南新聞』2010年 1 月 15 日

34 ）『毎日新聞』2010年 1 月 24 日

35 『十日町夕イムス』2010年 2 月 28 日

36 )『読売新聞』2010年 3 月 2 日

37 )『毎日新聞』2010年 3 月 10 日

38）『週報とおかまち』2010年 3 月 26 日

39）『新潟日報』2010年 3 月 30 日

40）『週報とおかまち』2010年4月 2 日

41）『新潟日報』2010年4月 3 日

42)『新潟日報』2010年 6 月 10 日

43)「社説」『十日町新聞』2009年 6 月 15 日

44）「重大な案件がある場合、知事の裁量で、市町村 長に同意を求める。」2010年 8 月 17 日電話で新潟 県庁土木部河川管理課水政係に聴き取りを行う。

45）「本案件については市民の方々の長年に亘る運 動があったため、市長の判断・裁量で市民に説 明し、市民の意向をお聞きした。」2010年 8 月 17 日電話で十日町市役所信濃川・清津川対策室に 聴き取りを行う。

46）JR 東日本 $($ 株 $)=$ 関係河川使用 3 者「試験放流に関 する確認書」 2010 年 3 月 30 日

47）国交省河川局水政課・開発課 $「$ 発電水利権の期 間更新時における河川維持流量の確保につい て」1988年7月 14 日

48) 2010 年 12 月 20 日、国土交通省に於いて聴き取り。

49）水利権実務研究会編著『新訂 水利権実務問答』 大成出版社、2005年8月 30 日

50）『河川砂防技術基準 (案)』1958年

51 ）『十日町新聞』2010年 2 月 5 日

52 )『十日町新聞』2010年 6 月 30 日

53)『十日町夕イムス』2009年 3 月 28 日

54）『毎日新聞』2009年 7 月 12 日

$55 ＼mathrm{~ 『 十 日 町 新 聞 』 2009 年 ~} 3$ 月 10 日

56）『新潟日報』21010年 4 月 5 日 